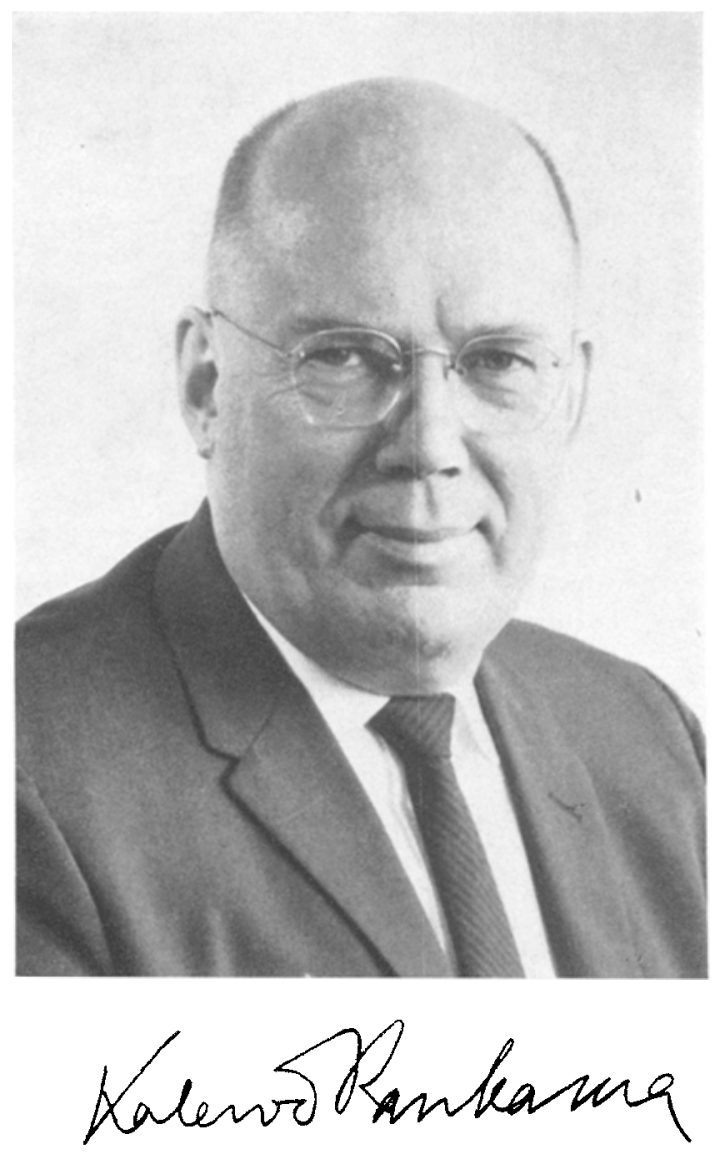

Die Geologische Vereinigung verlieh im Jahre 1971 die Gustav-Steinmann-Medaille

an

\title{
Professor Dr. Kalervo Rankama
}

der, auf grundlegenden geochemischen Forschungen aufbauend, die quantitativen Aspekte der Geologie erweiterte und durch diese und andere Arbeiten

Vermittler und Brückenbauer der Geowissenschaften wurde 